\title{
Promoting Values Together: Global Currency with Local Impact for Universities
}

\author{
Sijbolt Noorda and David-John Lock
}

The missions of the Magna Charta Observatory (MCO) and the International Association of Universities (IAU) have much in common. They both serve universities, are global in their reach but sensitive to local situations, and, fundamentally, they are based on values, values which have both global currency and local impact.

It is perhaps worth reflecting on why values are becoming ever more important. Universities today face greater complexity and uncertainty and have to respond more quickly. This is further complicated by the increasingly varied expectations of internal and more numerous and more diverse external stakeholders, the changing dynamics of national and international politics, increased competition for students and funding, challenges arising from internationalisation, the rapid evolution of technology and communication and occasional local and global emergencies, the current Coronavirus pandemic being a recent example. These challenges affect universities across the globe, regardless of their traditions, cultures, styles of operating, and missions. Decisions are required for which there is no recent precedent.

Values have, of course, been at the heart of universities since their formation and remain an essential tool in dealing with these challenges, offering universities guidance for their conduct and decision-making. Whether it is the traditional and more fundamental values of autonomy and academic freedom, social responsibility toward their community, or other values specific to institutional missions, values are crucial in helping universities understand and identify themselves and communicate that identity and mission to stakeholders.

\author{
S. Noorda $(\bowtie) \cdot$ D.-J. Lock \\ Observatory of the Magna Charta, Bologna, Italy \\ e-mail: s.j.noorda@uva.nl \\ D.-J. Lock \\ e-mail: davidjohn.lock@unibo.it \\ S. Noorda \\ University of Amsterdam, Amsterdam, The Netherlands \\ (C) The Author(s) 2021


To create and maintain public trust in universities amid today's complexity and uncertainty, universities need to define their values carefully and explicitly, clearly communicate them to staff, students, and stakeholders, and demonstrate that their values inform practice and decision-making.

The principles and values at the heart of the MCO are those set out in the Magna Charta Universitatum (MCU) which was first signed in 1988 by 388 rectors on the 900th anniversary of the founding of the University of Bologna. The first principle declared was independence: research and teaching must be intellectually and morally independent of all political influence and economic interests. The second was that teaching and research should be inseparable, with students engaged in the search for knowledge and greater understanding. The third principle identified the university as a site of free enquiry and debate, distinguished by its openness to dialogue and rejection of intolerance.

The original 1988 MCU outlined the values, scope and means of a common intellectual venture, based in Europe which was put together by many of its universities. According to the history, 'The Charter was to sum up in a few articles the main principles and values the universities can recognise as their common European inheritance. .... The power of intelligence, i.e., the capacity to link elements of knowledge in innovative ways for social and scientific development, was recalling its partners in society - the government, the church, the city fathers, representatives of trade and industry-'....' that its means and ends are at the centre of the European mind and behaviour, because they represent a shared way of life and thought' (Observatory Magna Charta Universitatum (n.d.) 2020).

Signing the Magna Charta committed universities to valuing autonomy and academic freedom and operating accordingly, as well as making public statements to this effect. Over 900 universities from 87 countries have now signed it.

Much has changed over that 30-year period, both in the contexts in which universities operate and within universities themselves. Enrolment in universities increased from $99.9 \mathrm{~m}$ in 2000 to $215.9 \mathrm{~m}$ in 2016 (UNESCO). It is projected to rise to $594 \mathrm{~m}$ by 2040. Estimates of the number of universities vary but have increased from around 10,000 in 2000 to over 25,000 by 2020 . With this growth come high expectations and also a growing appetite for control by governments, businesses and other stakeholders. This poses quite a challenge to autonomous universities.

Universities now operate more internationally, have to respond more quickly to larger numbers and more diverse learners and research requirements, use advanced technology, different modes of delivery and are challenged to be more sustainable and more equitable as well as serving the diverse needs of a wider range of local, national and international stakeholders. The recent pandemic requires a re-think of pedagogy and assessment procedures to ensure the safety of students and staff while enabling them to continue to study and derive the full range of benefits of traditional programmes - and to do so in a way that maintains public confidence in the process and outcomes.

Universities are seen as critical players in the achievement of the UN's Sustainable Development Goals (SDGs). Although education is only mentioned in the title of 
SDG 4, research and other university involvement are also required for successful achievement of each of the other 16 goals.

Furthermore, the growth in the number and variety of league tables for different purposes and the range of indicators to provide supporting evidence makes the performance of universities more transparent and more open to scrutiny.

Universities are consequently having to review their values; how they are given effect and how they contribute to the maintenance and development of their mission and reputation, as well as specific responses.

Over the past 20 years, the MCO, which is an association of signatories, was formed to assist with monitoring, enhancing and advising on the status of academic freedom and institutional autonomy. It organised annually an anniversary conference, commissioned reports, produced publications and engaged in other activities including lobbying, advocacy, publications to support universities worldwide as well as developing thinking on and practising of values in university life with a view to helping universities to reinforce trust in their relationship with their communities.

Often working with IAU, for instance on the joint IAU-MCO Guidelines for an Institutional Code of Ethics in Higher Education (2012), the MCO has, in addition to the activities above, increased significantly the number of regional workshops which it has convened to address the ways in which changes in society are impacting on universities.

In response to the findings from these workshops in 2016, the MCO embarked on two major projects. The first was the development of the Living Values project. This was designed to help universities identify, adopt and live by values that enable them to fulfil their mission and engage with their community successfully. The thinking behind the project is that reviewing and articulating values with the input of stakeholders will increase community engagement and create more trust between the institution and its staff, students, and stakeholders. Guidelines help universities to ensure that the values they espouse reflect the institution's mission and community; staff, students, and stakeholders have been effectively engaged in defining those values; and all members of the institution are able to articulate and effectively live by these defined values.

The second major project was to develop a new MCU to take account of the societal changes which have affected universities since 1988. Determining the process of doing this and how the vast amount of evidence was to be analysed so as to produce a document of less than two pages which would have global applicability and also be locally sensitive was critical for its success.

The task of preparing the draft 'MCU 2020' was given to an internationally diverse group of experienced higher education professionals, including a student leader. Members of the group reviewed the current and emerging situations in their part of the world, examined declarations from different countries which were written in different circumstances for different purposes and identified priorities for the new Magna Charta Universitatum.

The new Magna Charta Universitatum retains all the principles and values set out in the 1988 edition to which universities signed up. It strives to be responsive to and resonate with contemporary challenges and concerns. Its tone recognises that 
the pursuit of the fundamental values has worth along with their actual attainment, which, in practice, is a constant quest. It recognises the more global nature of what universities do and the wider range of local responsibilities which they have. It sets out principles, values and responsibilities which universities are invited to sign up to. It makes more explicit the importance of sustainability, civic responsibility, respect for diversity, equity, fairness and access to higher education. If they put them into practice, the contract between universities and society should become stronger, despite that fact that ever more dynamic changes are likely to come into play over the next 30 years.

The MCO's collaboration with IAU has played an important part in informing and launching the Living Values Project (n.d.) (2020) and developing MCU 2020. That collaboration will continue to further understand where and how values have impact, to share this learning and together enabling universities to best serve society.

The MCO 2020 will be formally launched in June 2021 in Bologna. We hope it will stimulate as well as support and protect a keen engagement with values in universities worldwide. At the end of the day, one should realise that-although declarations like MCO 2020 are valuable vehicles of principle and purpose-it is only through joint action and courageous advocacy that the global community of universities can protect and practice its ideals.

\section{References}

Living Values project. (n.d.). Retrieved from: http://www.magna-charta.org/activities-and-projects/ living-values-project (19.07.2020)

Magna Charta Universitatum. (2020). Retrieved from: http://www.magna-charta.org/magnacharta-universitatum/read-the-magna-charta/the-magna-charta (19.07.2020)

Observatory Magna Charta Universitatum. (n.d.). History, Retrieved from: http://www.magnacharta.org/magna-charta-universitatum/history (19.07.2020)

Sijbolt Noorda is Former President of the Governing Council of the Magna Charta Observatory. $\mathrm{He}$ is President Emeritus of the University of Amsterdam, past president of the Association of Dutch Research Universities and a former board member of the European University Association. His academic field is cultural history of religions in Europe. He holds degrees from Free University Amsterdam, Utrecht University and Union Seminary/Columbia University, NYC.

David-John Lock is Secretary General of the Magna Charta Observatory. He was International Director of the UK's Leadership Foundation, the founding Chief Executive and Registrar of the British University in Dubai and the administrative head of two UK universities. He holds degrees from the University of Bath. 
Open Access This chapter is licensed under the terms of the Creative Commons Attribution 4.0 International License (http://creativecommons.org/licenses/by/4.0/), which permits use, sharing, adaptation, distribution and reproduction in any medium or format, as long as you give appropriate credit to the original author(s) and the source, provide a link to the Creative Commons license and indicate if changes were made.

The images or other third party material in this chapter are included in the chapter's Creative Commons license, unless indicated otherwise in a credit line to the material. If material is not included in the chapter's Creative Commons license and your intended use is not permitted by statutory regulation or exceeds the permitted use, you will need to obtain permission directly from the copyright holder. 